\title{
PELATIHAN DEKORASI MERANGKAI JANUR PADA PEMUDA KARANG TARUNA DESA KUMELEMBUAI I KEC KUMELEMBUA KABUPATEN MINAHASA SELATAN
}

\author{
Jans G. Mangare \\ Fakultas Bahasa dan Seni, Universitas Negeri Manado
}

\begin{abstract}
Pelaksanaan pengabdian padamasyarakat ini berjudul: Pelatihan Dekorasi Merangkai Janur Pada Pemuda Karang Taruna Desa Kumelembuai I Kec Kumelembuai Kabupaten Minahasa Selatan. Kegiatan ini sebagai salah satu alternative untuk meningkatkan keahlian dan ke trampilan pada pemuda karang taruna agar mereka mampu menghadapi tantangan dalam era globalisasi. Melihat perkembangan saat ini dimana banyak pemuda yang putus sekolah dan memerlukan kegiatan-kegiatan yang positif sehingga perlu dilaksanakan kegiatan seperti ini untuk menfasilitasi kegiatan pemuda tersebut. Kegiatan dekorasi dapat dilaksanakan oleh siapa saja dan memerlukan ketrampilan khusus, untuk mendapatkan keterampilan tentunya perlu pelatihan-pelatihan.

Tujuan pelatihan ini adalah dikhususkan pada pemuda karang taruna yang merupakan organisasi kemasyarakatan yang ada di Desa Kumelembuai I dengan pertimbangan bahwa mereka masih dapat meluangkan waktu untuk mengikuti pelatihan, manfaat pelatihan ini yaitu untuk meningkatkan sumber daya manusia, kesejahteraan atau kewirausahaan.
\end{abstract}




\section{PENDAHULUAN}

Pemberdayaan pemuda merupakan satu hal yang perlu memerlukan pikiran dan tenaga karena yang dihadapi dalam masa kepemudaan itu begitu kompleks sehingga perlu di fasilitasi dalam kegiatan yang positif, karena pembangunan yang ada harus melibatkan pemuda seutuhnya. Dengan adanya kegiatan ini tentunya dapat memberikan nilai tambah bagi pemuda dalam menghadapi pembangunan di pedesaan.

Kegiatan pengabdian kepada masyarakat ini bertolak dari suatu kondisi permasalahan yang dialami khalayak sasaran. Kegiatan ini fokuskan pada masalah yang dihadapi pemuda karang taruna Desa Kumelembuai I kec. Kumelembuai Yaitu (1) Rendahnya pengetahuan dan keterampilan pemuda dalam mendekorasi ruang. (2) Perlu adanya pelatihan merangkai janur bagi pemuda. Kegiatan ini penting dilaksanakan dikarenakan Desa Kumelembuai I merupakan desa ibu kota Kecamatan sering dikunjungi oleh tamu- tamu yang di luar untuk melaksanakan kegiatan dan tentunya dalam kegiatan tersebbut memerlukan penataan ruangan. Kegiatan ini juga terasa penting diajarkan karena dapat memberikan penghasilan tambahan bagi pemuda yang ingin menekuni kegiatan tersebut bahkan kegiatan ini juga dapat menyalurkan bakat- bakat seni mendekorasi ruangan baik ruang tertutup dan ruang terbuka.

\section{KAJIAN LITERATUR DAN PEGEMB ANGAN HIPOTESIS \\ Target}

Seni dekorasi adalah pengistilahan yang popular di pergunakan akhir-akhir ini, yang bukan saja masyarakat awam tetapi oleh kaum terpelajar. Seni dekorasi adalah bagian dari seni rupa yang pada hakekatnya adalah applied art atau seni pakai. Kata seni dekorasi berarti terdiri dari dua kata seni dan dekorasi. Ada beberapa pendapat para ahli yang mengatakan sebagai berikut :

- Suatu usaha untuk menciptakan bentukbentuk yang menyenangkan. Bentuk yang menyenangkan itu memuaskan kesadaran keindahan kita dan rasa indah ini terpenuhi bila kita biasa menenmukan kesatuan atau harmoni dari bentuk- bentuk yang kita amati.

- Seni adalah ungkapan atau curahan kesadaran nilai estetik watak pribadi seseorang atau suatu masyarakat dalam hubungannya dengan dunia alam sekitar.

- Seni merupakan tindak lanjut dari daya cipta keindahan terhadap Tuhan pencipta alam semesta ini.

Sedangkan dekorasi berasal dari bahasa Yunani Kuno Dekore yang berarti menghias atau tanda, dan berasal dari bahasa asing, Decoration yang berarti menghias. Mneghias adalah segala daya upaya kegiatan untuk menghasilkan wujud benda artinya bahwa yang mengartikan benda tersebut memiliki nilai prakris dan estetik yang berimbang.

a. Bagian- bagian seni dekorasi

1. Interior decoration ( dekorasi dalam ruang) benda yang ada di dalam ruangan misalnya kursi , meja, lemari,dinding, bufat, lantai, kerajinan yang di gantung atau di letakkan juga aquarium, kolam yang pada prinsipnya di komposisikan.

2. Exterior decoration ( dekorasi luar Ruangan) dekorasi di luar ruangan kebanyakan adalah pertamannan/taman, patung, pagar, jembatan, dan jalan. Pembuatan taman haruslah di sesuaikan luas sempitnya halaman agar pertamannan itu berfungsi artistic, pengukuh hubungan antar manusia agar karya sangat di kagumi oleh penglihat sehingga memberi kesan tenang, penuh kesejukkan, dan penuh kedamaian. Dimaksudnkan pula sebagai ibadat atau sebagai rasa cinta bakti kepada pencipta agung.

3. Ceremony decoration (dekorasi kegiatan upacara) biasanya yang di utamakan dalam upacara ini adalah kostum, komposisi ruangan, hiasan peralatan dan tak kalah pentingnya acara upacara termasui protokoler

b. Prinsi cipta seni.

Suatu kejadian umumnya akan berhasil apabila dijalankan sesudah di rencankan. Jadi hal ini perencanaan yang baik menghasilkan hasil yang baik pula.

Dalam mencipta karya deokrasi yang bermutu, di perlukan suatu perencanaan yang di sebut desain atau nirmana. Nirmana (design) adalah suatu kegiatan menyusun konsep ide yang berubah unsur- unsur rua yang mengutamakan segi artistic sebelum menyatukan dalam bentuk karya yang final. Yang di maksud unsur- unsur rupa dalam bentuk seni rupa itu ialah : titik- titik 
( bintik- bintik), garis- garis, bidang- bidang, masa, warna, dll.

Berdasarkan hal tersebutdi atas maka seni dekorasi dapat di bedakan dalam arti yang luas dan arti yang sempit.

a. Arti sempit yaitu tanda- tanda kehormatan, penghias pakaian/badan sebagai bukti/ penahargaan atas kebijakkan, keberanian atan kepahlawannan serta penegas fungsi seseorang.

b. Arti luas yaitu bentuk- bentuk hiasan untuk memperindah dan menegaskan fungsi sesuatu (orang,benda, tempat maupun waktu)

Bertolak dari ungkapan- ungkapan itu maka dapat di artikan seni dekorasi adalah

- Karya- karya artistic sebagai ekspresi dan komunikasi yang bermutu tinggi dari seseorang atau masyarakat, untuk memeperindah rupa dan bentuk, menegaskan fungsi seseorang atau semata benda serta menyemarakkan tempat dan waktu benda.

- Seni dekorasi adalah usaha mengatur dan menciptakan suasana atau keadaan agar menjadi mulia, damai hikmat demi memuliakan bapa di sorga.

c. Bagian- bagian seni dekorasi

1 Interior decoration ( dekorasi dalam ruang) benda yang ada di dalam ruangan misalnya kursi , meja, lemari,dinding, bufat, lantai, kerajinan yang di gantung atau di letakkan juga aquarium, kolam yang pada prinsipnya di komposisikan.

2 Exterior decoration ( dekorasi luar Ruangan) dekorasi di luar ruangan kebanyakan adalah pertamannan/taman, patung, pagar, jembatan, dan jalan. Pembuatan taman haruslah di sesuaikan luas sempitnya halaman agar pertamannan itu berfungsi artistic, pengukuh hubungan antar manusia agar karya sangat di kagumi oleh penglihat sehingga memberi kesan tenang, penuh kesejukkan, dan penuh kedamaian. Dimaksudnkan pula sebagai ibadat atau sebagai rasa cinta bakti kepada pencipta agung.

3 Ceremony decoration (dekorasi kegiatan upacara) biasanya yang di utamakan dalam upacara ini adalah kostum, komposisi ruangan, hiasan peralatan dan tak kalah pentingnya acara upacara termasui protokoler
4 Prinsi cipta seni.

Suatu kejadian umumnya akan berhasil apabila dijalankan sesudah di rencankan. Jadi hal ini perencanaan yang baik menghasilkan hasil yang baik pula.

Dalam mencipta karya deokrasi yang bermutu, di perlukan suatu perencanaan yang di sebut desain atau nirmana. Nirmana (design) adalah suatu kegiatan menyusun konsep ide yang berubah unsur- unsur rua yang mengutamakan segi artistic sebelum menyatukan dalam bentuk karya yang final. Yang di maksud unsur- unsur rupa dalam bentuk seni rupa itu ialah : titik- titik ( bintik- bintik), garis- garis, bidang- bidang, masa, warna, dll.

Langkah- langkah yang di laksanakan dalam pembentukan suatu nirmana adalah :

- Pemilihan

- Pengolahan

\section{- Penyusunan}

Ketiga langkah itulah yang mendukung sehingga terbentuk suatu konsepsi (gabungan, perpaduan) yang harmonis maka terjadilah "variety in unity" ( aneka unsur dalam kesatuan). Variety in unity merupakan usaha nirmana dalam pemcapaian mutu keindahan dalam nirmana yaitu :

- Harmoni (keserasian)

- Ritme (ritma, Irama)

- Balance ( Keseimbangan)

Yaitu Penyusunan unsur- unsur sehingga mempunyai gerakkan yang hidup. Ada pula penyusunan unsur secara pengulangan dan bervariasi. Dalam penyusunan unsur- unsur ritma mempunyai pertalian dengan harmoni, di mana ritma merupakan unsur dalam proporsi yang menghasilkan kesatuan yang indah.

Balance (keseimbangan)

Yaitu Penyusunan unsur- unsur dalam suatu komposisi yang teratur. Balance di bedakan atas tiga jenis yaitu :

- Balance simetris

- Balance asimetris

- Balance sentral

a. Balance simetris : unsur- unsur dalam kesatuan di mana bagian yang satu dan bagian yang lain sama atau hampir bersamaan (Gambar 3) Blance ini sudah menjadi klasik dan mengandung kesan tenang.

b. Balance asimetris : unsur- unsur dalam kesatuan dengan menciptakan dominasi unsur yang harmonis ( Gambar 4) yang 
berarti pula kiri dan kanan tidak sama. Balance ini menpunyai kesan dinamis.

c. Balance sentral : Balance yang menpunyai susunan unsur yang menebar dan sentris. ( Gambar 5) Yang memberikan kesan tenang dan hikmat.

Alat Dan Bahan

1. Alat- alat :

- Pisau kecil/ pisau silet lipat tipis dan tajam untuk memotong buah atau daun sesuai yang di kehendaki.

- Jarum dan benang untuk menjahit dan mengikat

- Hekter untuk menjepit daun

2. Bahan :

- Pakupaying atau pines untuk melekatkan daun/ rangkaian kertas atau kain yang menjadi latar belakang/ alas suatu rangkaian.

- Kertas ( Metalik,Marmer,Krep) Untuk membungkus batang pisang, atau sebagai bahan penambah hiasan bagi satu rangkaian.

- Batang pisang untuk tempat menusukkan dan meletakkan sesuaturangkaian buah buahan dll.

- Pot bunga/ jabangan bunga untuk meletakkan batang pisang tempat rangkaian.

Jenis- Jenis bahan alam sekitar.

1. Daun- Daunan :

2. Jenis Bunga- Bungaan

3. Jenis Buah

4. Jenis Batang- batangan :

5. Jenis Akar- akaran :

6. Jenis Ubi- Ubian : Ketela, Jalar, kentang, Talas dsb.

7. Jenis Sayur- Sayuran.

8. Jenis Pelepah

2. METODE

1. Materi pelatihan ini di bagi atas 4 bagian yang meliputi

1.1 Penjelasan tentang pentingnya dekorasi merangkai janur

1.2 Pengenalan alat dan bahan

1.3 Pembuatan desain

1.4 Praktek pembuatan rangkaian janur

2. Metode dan Teknik Pelatihan

2.1 Metode Ceramah Yaitu memebrikan penjelasan tentang Pentinganya penataan ruan dengan menggunakan rangkaian janur.

2.2 Metode Tanya jawab

2.3 Latihan memebuata desain rangkaian janur

2.4 Membagi kelompok peserta agar tepat sasaran pelaksanaan pelatihan

\section{A. Media dan Pelatihan}

Media dan bahan pelatihan berupa janur, btang pisang, kater, gunting, alat tulis menulis, buku gambar, contoh- contoh rangkaian janur, leptop dan LCD.

\section{B. Evaluasi}

1. Evaluasi formatif pada akhir setiap kegiatan

2. Evaluasi proses pembelajaran dan pelatihan

3. Evaluasi Sumatif pada akhir pelatihan

\section{HASIL DAN PEMB AHASAN}

Pemuda karang teruna merupakan satu organisasi kepemudaan yang ada di Desa Kumelembuai I Kec. Kumelembuai. Organisasi kepemudaan ini begitu aktif dalam kegiatan kepemudaan dan juga banyak membantu pemerinta dalam melaksanakan pembangunan pedesaan.

Kecendrungan sekarang masyarakat dalam menata ruangan untuk menerima tamu-tamu atau pejabat banyak mengunakan bahan plastic atau bahan industrial. Hal ini yang membuat saya yang punya keahlian dalam penataan ruangan terpangil untuk melaksanakan kegiatan tersebut. Peserta yang dilibatkan dalam pelatihan ini hanya dibatasi pada pemuda yang telah putus sekolah dengan pertimbangan bahwa mereka mengikuti kegiatan ini lebih focus sehinga dapat menghasilkan latihan yang baik.

Pelaksanaan kegiatan ini para peserta sangat merespons dilihat dari keseriusan peserta mengikutinya sehingga pelaksanaan yang dilaksanakan selama 2 minggu ini hasilnya sangat memuaskan, para peserta begitu tekun dan karya-karya meraka sangat baik hasilnya. Para peserta masih mengharapkan kelanjutan dari kegiatan ini karena mereka telah dapat merasakan secara langsung kegunaan dari kegiatan ini

Materi yang diberikan kepada perserta pelatihan berorientasi pada lingungan sekitar para peserta pelatihan seperti memanfaatkan bahan alam yang mudah didapat dan ramah lingkungan, 
begitupun dalam pembuatan disain ruangan lebih berorientasi bagaimana menata ruang dengan memanfaatkan bahan alam sekitar yang murah tapi meriah.

\section{Kepus takaan}

Bastomi, Suaji. 1986. Kebudayaan apresiasi seni, pendidikan Seni. Semarang : IKIP Pers

Garha, Oho. 1998. Pokok- pokok pengajaran kerajinan tangan dan kesenian. Jakarta : Departemen Pendidikan dan Kebudayaan

Hartoko, Dick, 1984. Manusia Seni. Yogyakarta : kanisius

Isbandi, Budi, 1986. Lukisan Sebagai potret diri. Surabaya : Dewan kesenian

Ismianto, P.C. 1994. Pembelajaran Pendidikan Seni Rupa Di Sekolah Dasar, Semarang : Media FPBS No. 03

Kristanto.1994. Wanita Dan Problematikanya, Prespektif

Panitia Lokakarya Pendidikan Seni Rupa, 2001. Konsep Pendidikan Seni Rupa Di Sekolah dasar, Jakarta

Poerwadarminto, W.j.s. Aming, 1990. Kamus Besar Bahasa Indonesia, Jakarta : Depdikbut

Raharjo, Budhy, 1986. Himpunan Materi Pendidikan seni. Malang :Yrama

Soedarso, S.P.1987. Tinjauan Seni(Sebuah Pengantar Apresisasi Seni) Yogyakarta :

Saku Dayar Sana 